\title{
Effect of supplementation of guanidinoacetic acid and arginine in vegetable diets for broiler on performance, carcass yield and meat quality
}

\section{Efeito da suplementação de ácido guanidinoacético e arginina em dietas vegetais para frangos de corte sobre o desempenho, rendimento de carcaça e qualidade de carne}

\author{
Aline Fernanda Gonçalves Esser ${ }^{1}$; Thaís Lina Taniguti ${ }^{2}$; Alexandra Maria da Silva ${ }^{2}$; \\ Elisangela Vanroo²; Isabelle Naemi Kaneko ${ }^{3}$; Tatiana Carlesso dos Santos; \\ Jovanir Inês Müller Fernandes ${ }^{5 *}$
}

\begin{abstract}
Birds fed with vegetable diets rely on the endogenous synthesis of creatine, which requires amino acids, some of which, for example arginine (Arg), are considered essential for several physiological and metabolic functions. Creatine is limited to high energy expenditure cells, particularly muscle cells. The objective of this study was to evaluate the inclusion of guanidinoacetic acid and arginine (as precursors of creatine) in vegetable diets, on the performance, quality, and yield of broiler chickens. The treatments consisted of diets based on corn and soybean meal (T1); corn, soybean meal $+3 \%$ meat meal (T2); corn, soybean meal $+0.08 \%$ guanidinoacetic acid (T3); and corn, soybean meal $+0.08 \%$ L-arginine (T4). The productive performance of the birds aged 7-, 21-, and 42-days-old was determined. Eighteen 7-day-old birds were sacrificed per treatment to evaluate breast and leg yield, and breast muscle fibers, and eighteen 42-day-old birds were sampled per treatment to determine serum uric acid, urea, creatine, lactate, and glucose concentrations. The same birds were slaughtered to calculate carcass yield in relation to live weight and commercial cut yield. The right pectoralis major muscle of each bird was used to test $\mathrm{pH}$, color (luminosity $\mathrm{L}^{*}$, red index $\mathrm{a}^{*}$, and yellow index $\mathrm{b}^{*}$ ), and loss of water by pressure analysis, and the left side was used to analyze losses by defrosting and cooking. The data were analyzed using the software SAS. Diets to which meat or vegetable meal plus guanidinoacetic acid or L-Arginine were added resulted in higher live weight and breast meat percentage at 7 days old. Feed conversion was affected for a total period of 1 to 42 days of age $(\mathrm{P}<0.0002)$. The birds with a diet supplemented with vegetable and meat meal had better feed conversion when compared to the birds that were fed with other diets. Treatments did not affect carcass and commercial cut yields, percent loss by cooking, pressure and defrosting of the broiler breast meat, or color ( $\mathrm{L}, \mathrm{a}^{*}$, and $\left.\mathrm{b}^{*}\right)$ and $\mathrm{pH}$ values.
\end{abstract}

Key words: Weight gain. Glycine. ATP re-synthesis.

\footnotetext{
' Discente, Curso de Mestrado, Programa de Pós-Graduação em Ciência Animal, PPGCA, Universidade Federal do Paraná, UFPR, Palotina, PR, Brasil. E-mail: alinefesser@gmail.com

2 Discentes, Curso de Graduação de Medicina Veterinária, UFPR, Palotina, PR, Brasil. E-mail: thaislinataniguti@gmail.com; alexandramila@gmail.com; elisangela.vanroo@gmail.com

3 Discente, Curso de Doutorado, Programa de Pós-Graduação em Zootecnia, PPZ, Universidade Estadual de Maringá, UEM, Maringá, PR, Brasil. E-mail: isabelle naemi@hotmail.com

4 Profa, Programa de Pós-Graduação em Zootecnia, PPZ, UEM, Maringá, PR, Brasil. E-mail: tcsantos@uem.br

5 Prof ${ }^{a}$, Programa de Pós-Graduação em Ciência Animal, PPGCA, UFPR, Palotina, PR, Brasil. E-mail: jimfernandes@ufpr.br

* Author for correspondence
} 


\section{Resumo}

Aves alimentadas com dietas vegetais dependem da síntese endógena de creatina, que requer a participação de aminoácidos, alguns deles considerados essenciais para diversas funções fisiológicas e metabólicas, como a arginina (Arg). A creatina limita-se a células de alto gasto energético, em particular as células musculares. O objetivo foi avaliar a inclusão do ácido guanidinoacético e de arginina como precursor da creatina em dietas vegetais sobre o desempenho, a qualidade e o rendimento de carcaça de frangos de corte. Os tratamentos consistiram em dietas baseadas em milho e farelo de soja (T1); dieta a base de milho, farelo de soja $+3 \%$ de farinha de carne (T2); dieta a base de milho e farelo de soja $+0,08 \%$ de ácido guanidinoacético (T3) e dieta a base de milho e farelo de soja $+0,08 \%$ de L-arginina (T4). O desempenho produtivo das aves foi determinado aos 7, 21 e 42 dias de idade. Aos sete dias de idade, 18 aves/tratamento foram sacrificadas para avaliação do rendimento de peito e pernas e para fibras musculares do peito. Aos 42 dias de idade foi coletado sangue de 18 aves/tratamento para a determinação das concentrações séricas de ácido úrico, uréia, creatina, lactato e glicose. As mesmas aves foram abatidas, para o cálculo de rendimento de carcaça em relação ao peso vivo e rendimento de cortes nobres. O músculo Pectoralis major direito de cada ave foi utilizado para as análises de $\mathrm{pH}$, cor (luminosidade $\mathrm{L}^{*}$, índice de vermellho $\mathrm{a}^{*} \mathrm{e}$ índice de amarelo $\mathrm{b}^{*}$ ) e a perda de água por pressão e o lado esquerdo para as análises de perdas por descongelamento e por cozimento. Os dados foram analisados pelo software SAS. As dietas com adição de farinha de carne ou vegetais acrescidas de ácido guanidionacético ou L-Arginina resultaram em maior peso vivo e percentual de carne de peito aos sete dias. Para o período total de 1 a 42 dias de idade, observou-se efeito $(\mathrm{P}<0,0002)$ sobre a conversão alimentar. As aves suplementadas com dieta vegetal e farinha de carne apresentaram melhor conversão alimentar quando comparadas às aves que receberam as demais dietas. Para o rendimento de carcaça $\mathrm{e}$ dos cortes comerciais, percentual de perda por cozimento, por pressão e por descongelamento da carne de peito de frangos de corte e para os valores de cor L, a e b e de $\mathrm{pH}$ não foram observadas diferenças significativas entre os tratamentos.

Palavras-chave: Ganho de peso. Glicina. Re-síntese de ATP.

\section{Introduction}

Creatine, also known as $\alpha$-methylguanidineacetic acid (CREA), has two important functions as a precursor of creatine phosphate $(\mathrm{PCr})$ in muscle metabolism: it carries high-energy phosphate molecules from the mitochondria to the myosin filaments and acts as a reservoir of high-energy phosphate, which can regenerate adenosine triphosphate (ATP) from adenosine diphosphate (ADP) (WALKER, 1960). CREA does not occur in all cells, but is limited to high-energy-expenditure cells, particularly muscle cells. CREA storage occurs in both free and phosphorylated forms. About $95 \%$ of body CREA is stored in the skeletal muscles, of which about $60-70 \%$ is stored in the form of $\mathrm{PCr}$, which is unable to pass through cell membranes, thereby keeping the CREA in the cell (GREENHAFF, 1997).
Birds fed with vegetable diets depend exclusively on endogenous synthesis of CREA, which occurs using the amino acids glycine (Gly), methionine (Met), and arginine (Arg). The first step in CREA synthesis is the reversible transfer of the amidine group from Arg to Gly to form GAA and ornithine, in a reaction catalyzed by the enzyme arginine:glycine amidinotransferase (AGAT). In a second reaction, catalyzed by guanidinoacetate $\mathrm{N}$-methyltransferase, guanidinoacetate is methylated by S-adenosylmethionine (SAM) to form S-adenosylhomocysteine and CREA(BLOCH; SCHOENHEIMER, 1941). CREA is released by the liver and is collected mostly by muscle tissue, where it is stored as $\mathrm{PCr}$ or converted to creatinine. Therefore, Arg and Gly depend on a supply of CREA for an adequate energy supply for muscle protein synthesis, especially when considering the 
muscle growth rate of the modern lineages of broiler chickens. On the other hand, birds are not able to synthesize Arg and therefore depend on a supply of this amino acid in their diet (BALL et al., 2007). The demand for Arg is high, either due to a lack of endogenous synthesis, high protein content and deposition due to the rapid growth of the chicken, or to the antagonistic metabolic interaction between Lys and Arg (EDMONDS; BAKER, 1987).

Arginine (Arg), an amino acid considered essential for birds, is also important for a range of biological and physiological functions, including protein biosynthesis, nitrogen transport and excretion, polyamine and nitric oxide (NO) production, and stimulation of hormonal secretion (for example, of IGF-I) (EFRON; BARBUL, 2000). Glycine (Gly), considered a conditionally essential amino acid, performs countless functions in protein synthesis, takes part in the metabolism of bile acids (glycocholic acid) and of glutathione, and performs an important function in nitrogen excretion by supplying two carbon and nitrogen atoms for uric acid synthesis (KIDD; KERR, 1996; MAPES; KREBS, 1978).

The use of animal protein-such as meal resulting from the slaughter of poultry, pigs, and cattle-in the formulation of broiler diets is limited due to the requirements of poultry import markets, although it is considered to "save" Arg and Gly, both of which are CREA sources. Thus, broiler diets composed basically of corn and soybean meal may compromise the adequate nutrient balance.

Supplementing vegetable diets with CREA is not considered feasible due to its instability and high cost (WIETLAKE et al., 1954). However, diets with high Arg levels can stimulate the formation of CREA in the muscle tissue of broilers (CHAMRUSPOLLERT et al., 2002), but this amino acid is not commercially available for animal diets. On the other hand, GAA (also known as glucosamine or guanidinoacetate), is a precursor of CREA and has the potential to be used as an additive in the feed formulation for broilers. This compound may save dietary Arg and Gly, since GAA is an immediate precursor of CREA, requiring only the transfer of a methyl group from Met (BAKER, 2009).

Studies on broiler chickens supplemented with GAA reported a change in $\mathrm{pH}$ and luminosity of broiler meat (STAHL et al., 2003; NISSEN; YOUNG, 2006), significant improvements in performance, a higher percentage of breast meat (RINGEL et al., 2008; MICHIELS et al., 2012), and increased muscle CREA (MICHIELS et al., 2012).

Dilger et al. (2013) observed a significant improvement in weight gain and feed conversion of 8- to 17-day-old chicks, when GAA was added to their diet (which was based on dextrose and casein and therefore, deficient in Arg). According to these authors, GAA can be substituted for dietary Arg, as demonstrated with broiler strains in the 1960s (SAVAGE; O'DELL, 1960).

The objective of this study was to evaluate the effects of guanidinoacetic acid and arginine, added to vegetable diets, on the productive performance, muscle development, and functional properties of meat from broiler chickens aged 1 to 42 days.

\section{Material and Methods}

The experiment was conducted in the Experimental Aviary of the Federal University of Paraná, Palotina Sector. All procedures for animal farming and sampling of biological material were approved by the Ethics Committee on the Use of Animals in Experimentation - Protocol no. 12/2013 CEUA/Palotina.

A total of 1260 male, 1-day-old broiler chicks from the Cobb lineage, from approximately 40 -weekold breeders, were distributed in a completely randomized experimental design with 3 treatments, 9 replicates, and 35 birds per experimental unit. The treatments consisted of (T1) a vegetable control diet based on corn and soybean meal, (T2) a vegetable control diet based on corn and soybean meal plus 
meat meal (3\%), (T3) a vegetable diet based on corn and soybean meal plus guanidinoacetic acid $(0.08 \%)$, and (T4) a vegetable diet based on corn and soybean meal plus L-Arginine (0.8\%).

The CreAMINO $^{\circledR} \quad(96 \%$ guanidinoacetic acid; Evonik Degussa) commercial source of guanidinoacetic acid, and the L-Arginine (99\% Arginine, Ajinomoto) source of Arg were used.
The rations were formulated following the chemical composition values of the food and the nutritional recommendations adopted by the poultry integrations of the region, in a three-phase feeding program: initial (1 to 21 days), growth (22 to 37 days), and slaughter phase (38 to 42 days) (Table 1 ). The birds received feed and water ad libitum during the experimental period.

Table 1. Nutritional composition of experimental diets: starter (from 1 to 21 days of age), grower (from 22 to 37 days of age) and finisher (from 38 to 42 days of age).

\begin{tabular}{|c|c|c|c|c|c|c|}
\hline \multirow[t]{2}{*}{ Ingredients, $\mathrm{kg}$} & \multicolumn{2}{|c|}{ Starter } & \multicolumn{2}{|c|}{ Grower } & \multicolumn{2}{|c|}{ Finisher } \\
\hline & $\mathrm{T} 2$ & $\mathrm{~T} 1, \mathrm{~T} 3, \mathrm{~T} 4$ & $\mathrm{~T} 2$ & $\mathrm{~T} 1, \mathrm{~T} 3, \mathrm{~T} 4$ & $\mathrm{~T} 2$ & $\mathrm{~T} 1, \mathrm{~T} 3 \mathrm{~T} 4$ \\
\hline Corn & 62.20 & 60.30 & 65.08 & 62.64 & 67.76 & 65.13 \\
\hline Soybean meal (46\%) & 32.40 & 35.20 & 27.60 & 30.80 & 18.13 & 17.07 \\
\hline Soybean micronized & - & - & - & - & 9.33 & 14.67 \\
\hline Soybean oil & - & 0.8 & 2.2 & 3.10 & - & - \\
\hline Meat meal (45\%) & 3.0 & - & 3.0 & - & 3.0 & - \\
\hline Sodium chloride & 0.300 & 0.340 & 0.280 & 0.320 & 0.320 & 0.373 \\
\hline Inert $^{1}$ & 0.100 & 0.100 & 0.100 & 0.100 & 0.100 & 0.100 \\
\hline Limestone & 0.560 & 0.940 & 0.460 & 0.940 & 0.480 & 0.907 \\
\hline Dicalcium phosphate & 0.140 & 1.060 & 0.080 & 0.900 & - & 0.853 \\
\hline Sodium bicarbonate & 0.100 & 0.100 & 0.100 & 0.100 & - & - \\
\hline DL-Met $98 \%$ & 0.284 & 0.279 & 0.191 & 0.183 & 0.192 & 0.189 \\
\hline L-Lysine $50.7 \%$ & 0.385 & 0.358 & 0.418 & 0.372 & 0.360 & 0.333 \\
\hline L-Threonine 98\% & 0.086 & 0.078 & 0.032 & 0.020 & 0.059 & 0.053 \\
\hline L-Tryptophan 98\% & - & - & 0.006 & - & - & - \\
\hline Choline chloride $60 \%$ & 0.042 & 0.040 & 0.045 & 0.042 & 0.031 & 0.025 \\
\hline Vit. e mineral premix $x^{2,3}$ & 0.400 & 0.400 & 0.400 & 0.400 & 0.300 & 0.300 \\
\hline \multicolumn{7}{|l|}{ Calculated values } \\
\hline Crude protein, $\%$ & 21.67 & 21.43 & 19.64 & 19.51 & 18.66 & 18.44 \\
\hline $\mathrm{ME}(\mathrm{Kcal} / \mathrm{kg})$ & 2950 & 2950 & 3130 & 3130 & 3153 & 3153 \\
\hline Calcium & 0.881 & 0.850 & 0.817 & 0.821 & 0.800 & 0.786 \\
\hline Available Phosphorus & 0.439 & 0.442 & 0.420 & 0.419 & 0.400 & 0.395 \\
\hline Dig. Lysine, $\%$ & 1.199 & 1.201 & 1.100 & 1.101 & 1.001 & 0.999 \\
\hline Dig.Met+Cys, \% & 0.864 & 0.864 & 0.727 & 0.727 & 0.701 & 0.700 \\
\hline Dig. Threonine, $\%$ & 0.780 & 0.780 & 0.660 & 0.660 & 0.648 & 0.648 \\
\hline Dig. Tryptophan, \% & 0.222 & 0.230 & 0.203 & 0.208 & 0.182 & 0.190 \\
\hline Dig.Leucine, \% & 1.636 & 1.643 & 1.510 & 1.525 & 1.435 & 1.432 \\
\hline Dig. Isoleucine, $\%$ & 0.824 & 0.843 & 0.737 & 0.763 & 0.678 & 0.690 \\
\hline
\end{tabular}


continuation

\begin{tabular}{lcccccc} 
Dig. Valine, \% & 0.902 & 0.904 & 0.816 & 0.825 & 0.758 & 0.753 \\
Dig. Arginine, \% & 1.296 & 1.297 & 1.158 & 1.159 & 1.080 & 1.080 \\
$\mathrm{Na}+\mathrm{K}-\mathrm{Cl}, \mathrm{meq} / \mathrm{kg}$ & 236 & 241 & 212 & 219 & 194 & 202 \\
\hline
\end{tabular}

${ }^{1}$ Inert: replaced by GAA e L-Arg

${ }^{2}$ Starter and grower premix (content per kg of premix): Folic acid 625.00mg; Pantothenic acid 4500.00mg; Amylase 50000.00U, Zinc bacitracin 13.75g; Biotin 50.00mg; Cupper 2000.00mg; Etoxin 16.65g; Iron 17.50g; Phytase 125000.00U; Iodine 250.00mg, Manganese 30.00g; Niacin 10.00g; Protease 1000000.00U; Selenium 60.00mg; Vitamin A. 3000000.00UI; Vitamin B1. 750.00mg; Vitamin B12. 5000.00mg; Vitamin B2. 2000.0mg; Vitamin B6. 1250.00mg; Vitamin D3. 875000.00UI; Vitamin E. 7500.00UI; Vitamin K3. $750.00 \mathrm{mg}$; Xylanase 500000.00U; Zinc 25.00g.

${ }^{3}$ Finisher premix (content per kg of premix): Folic acid 333.40mg; Pantothenic acid 4000.00mg; Amylase 66668.00U; Biotin 66.67mg; Cupper 2667.00mg; Iron 20.00g; Phytase 166570.00U; Butylate dhydroxytoluene 33.33g; Iodine 334.00mg, Manganese 33.33g; Niacin 10.00g; Protease 1333360.00U; Selenium 80.00mg; Vitamin A. 2333333.30UI; Vitamin B1. 500.00 mg; Vitamin B12. $4000.00 \mathrm{mg}$; Vitamin B2. $1567.00 \mathrm{mg}$; Vitamin B6. 1187.00mg; Vitamin D3. 833989.00UI; Vitamin E. 5657.00UI; Vitamin K3. $1000.00 \mathrm{mg}$; Xylanase 565580.00U; Zinc 25.57g.

The average weight and feed intake of the birds per experimental treatment, were recorded at the ages of 7, 21, and 42 days. The birds were weighed to calculate the feed conversion ratio in case of mortality.

A total of 18, 7-day-old birds were sacrificed per treatment ( 2 birds/experimental unit) through cervical dislocation. The chest and left leg were isolated, deboned, and weighed. Breast muscle (pectoralis major) samples were frozen in liquid nitrogen, cut in a cryostat microtome $(8 \mu \mathrm{m}$ thickness) oriented transversely to the muscle fibers, stained with hematoxylin and eosin, and analyzed under a light microscope (Olympus Bx40). Five digital images were obtained from each bird at $10 \times$ magnification, to determine the number of muscle fibers per unit area and muscular fiber diameters (100 fibers/bird), following the methodology described by Dubowitz (1985).

Blood of 42-day-old birds ( $\mathrm{n}=18 /$ treatment), with live weight $\pm 2 \%$ of the average weight of the caged birds, was used to determine the serum concentrations of uric acid, urea, creatine, lactate, and glucose. Serum samples remained frozen $(-20$ $\left.{ }^{\circ} \mathrm{C}\right)$ until the time of the biochemical analyses, which were performed using a Mindray ${ }^{\circledR}$ Medical Analyzer BS-200 (Mindray Medical International Limited) using DIALAB ${ }^{\circledR}$ brand commercial kits.
The same birds were then stunned by electronarcosis, slaughtered by bleeding, and then scalded, plucked, and eviscerated, following the MAPA normative instruction (BRASIL, 2000). The weight of the warm eviscerated carcass, without feet, head, and abdominal fat, was considered in relation to the live weight, which was obtained individually before the slaughter of the birds, to calculate carcass yield. The yield of the whole breast with skin and bones, and of the legs (thigh and drumstick with bones and skin)-calculated in relation to the weight of the eviscerated carcass-was analyzed to assess the performance of the commercial cuts.

The abdominal fat present around the cloaca, cloacal pouch, gizzard, pro-ventricle, and adjacent abdominal muscles was removed, weighed and calculated in relation to the weight of the eviscerated carcass (SMITH, 1993).

The right pectoral muscle (pectoralis major) of each bird was identified and maintained at room temperature for 15 minutes postmortem and $\mathrm{pH}$ was measured by the direct introduction of a glass electrode into the apical region of the muscle. The $\mathrm{pH}$ values were obtained 1 hour (initial $\mathrm{pH}$ ) and 24 hours after slaughter under refrigeration at 0 $\pm 2{ }^{\circ} \mathrm{C}$ (final $\mathrm{pH}$ ), with one reading at each time. Color measurements were obtained from the ventral surface of the $24 \mathrm{~h}$ postmortem fillet, at three different 
reading locations, namely the cranial, median, and caudal portions of each sample, arranged on a smooth white surface. The Minolta ${ }^{\circledR}$ colorimeter model CR10 was used for color measurement. The luminosity $L^{*}$, red index $a^{*}$, and yellow index $b^{*}$ values were expressed in the CIELAB color system.

A sample of two grams of the pectoralis major muscle (about $0.5 \mathrm{~cm}$ thick) was weighed on a semi-analytical scale, positioned between two filter papers (Whatman no. 1), and pressed with a weight of $10 \mathrm{~kg}$ between two acrylic plates for five minutes to evaluate its water retention capacity (WRC). The sample was weighed again to calculate the CRA, following the methodology proposed by HAMM methodology (1960), adapted by Wilhelm et al. (2010).

Cooking loss was calculated using the methodology adapted from López et al. (2011). The left pectoral muscle was weighed and then roasted in an electric oven preheated to $180{ }^{\circ} \mathrm{C}$ until an internal temperature of $72{ }^{\circ} \mathrm{C}$ (about 5 minutes on each side) was reached. After cooking, the samples were stored, cooled for 12 hours at $4 \pm 2{ }^{\circ} \mathrm{C}$, and weighed again.
The deep pectoral muscle (supracoracoideus) on the left side was weighed and frozen, and weighed again, after defrosting for 24 hours at $4 \pm 2{ }^{\circ} \mathrm{C}$, to evaluate fluid loss by defrosting.

For the statistical analysis, the data were checked for outliers, and the assumptions of normality of studentized errors (Cramer-von Mises test) and homogeneity of variance (Brown-Forsythe test) were tested. Having confirmed the non-violation of these assumptions, the data were submitted to an analysis of variance using the GLM procedure of the SAS program (SAS INSTITUTE, 2002). If significant differences were detected, the means of the test groups were compared using the Tukey's test.

\section{Results and Discussion}

A significant effect $(P=0.056)$ of diet on the live weight of the 7-day-old birds was observed (Table 2). Diets with meat or vegetable meal plus GAA or L-Arg showed similar results. However, no significant difference was observed in the performance of broilers for the periods of 1 to 21 days and 21 to 42 days.

Table 2. Productive performance of broiler chickens fed with diets including meat meal, GAA, or L-Arg.

\begin{tabular}{lcccccc}
\hline \multicolumn{1}{c}{$\begin{array}{c}\text { Performance } \\
\text { Variables }\end{array}$} & $\begin{array}{c}\text { Vegetable } \\
\text { Diet }\end{array}$ & $\begin{array}{c}\text { Vegetable Diet } \\
\text { + FC }\end{array}$ & $\begin{array}{c}\text { Vegetable Diet } \\
\text { +GAA }\end{array}$ & $\begin{array}{c}\text { Vegetable Diet } \\
\text { + L-Arg }\end{array}$ & CV, \% & P value \\
\hline Live weight, g & $204.07^{\mathrm{b}}$ & $212.65^{\mathrm{a}}$ & $205.98^{\text {ab }}$ & $206.23^{\text {ab }}$ & 3.24 & 0.0562 \\
Feed consumption, g & 193.00 & 203.86 & 197.79 & 198.89 & 5.48 & 0.2305 \\
Weight gain, g & 159.46 & 168.56 & 163.44 & 163.05 & 5.07 & 0.1611 \\
Feed conversion & 1.210 & 1.209 & 1.209 & 1.220 & 3.12 & 0.9052 \\
\hline \multicolumn{7}{c}{1 to 21 days } \\
\hline Live weight, g & 954.63 & 961.89 & 942.00 & 954.85 & 3.13 & 0.5641 \\
Feed consumption, g & 1355.94 & 1294.04 & 1346.4 & 1340.32 & 5.76 & 0.3424 \\
Weight gain, g & 847.12 & 821.69 & 863.37 & 837.19 & 4.46 & 0.1599 \\
Feed conversion & 1.595 & 1.583 & 1.588 & 1.606 & 2.62 & 0.6827 \\
\hline
\end{tabular}


continuation

\begin{tabular}{lcccccc}
\hline \multicolumn{7}{c}{21 to 42 days } \\
\hline Feed consumption, g & 3142.01 & 2931.01 & 3078.70 & 3097.93 & 5.95 & 0.0992 \\
Weight gain, g & 1704.12 & 1692.23 & 1670.88 & 1678.89 & 6.30 & 0.9148 \\
Feed conversion & 1.824 & 1.829 & 1.799 & 1.815 & 3.86 & 0,809 \\
\hline \multicolumn{7}{c}{1 to 42 days } \\
\hline Live weight, g & 2691.67 & 2709.03 & 2684.42 & 2673.81 & 4.29 & 0.9302 \\
Feed consumption, g & 4498.00 & 4225.01 & 4425.10 & 4438.20 & 4.97 & 0.0650 \\
Weight gain, g & 2551.23 & 2495.90 & 2354.24 & 2516.08 & 5.09 & 0.8196 \\
Feed conversion & $1.763 \mathrm{a}$ & $1.694 \mathrm{~b}$ & $1.746 \mathrm{a}$ & $1.764 \mathrm{a}$ & 1.870 & 0.0002 \\
\hline
\end{tabular}

$\mathrm{CV}$ : coefficient of variation.

A significant effect $(\mathrm{P}<0.0002)$ on feed conversion was observed for the total period of 1 to 42 days of age. The consumption of the diet supplemented with meat meal resulted in better feed conversion when compared to the other diets.

Bryant-Angeloni (2010) observed no positive influence on weight gain when GAA was added to Arg-deficient diets, but did report a gain in feed conversion. However, in Arg-sufficient diets, the results were significant for both weight gain and feed conversion. These results confirm that the addition of GAA to diets can produce performance responses, even when included in Arg-sufficient diets.

The reported effects of dietary GAA supplementation on the live weight of broilers have been contradictory. Some studies have demonstrated positive effects (VOLEK; BRANCH, 1998; VOLEK et al., 2004; RINGEL et al., 2008; DILGER et al., 2013), while others did not observe changes (LOUIS et al., 2003). A study developed by the EFSA Journal (2009) with 1- to 42-dayold broilers, using a pelleted vegetable diet (corn/ wheat/soybean meal), supplemented with 0 to 800 mg GAA per kg of diet, improved weight gain with supplementation of between 400 and $800 \mathrm{mg} \mathrm{kg}^{-1}$, while feed conversion was significantly improved from $400 \mathrm{mg} \mathrm{kg}^{-1}$. On the other hand, Mousavi et al. (2013) observed that supplementation of GAA $(0.06 \%)$ in the diet of 1 - to 40 -day-old broiler chickens increased feed intake but did not affect the weight gain of the birds. These results show a need for further studies on the supplementation of additives to provide energy substrates to the muscle. The search for improvements in productive performance is fundamental since investments in nutrition are high and thus the return must be economically viable.

The percentage weight of the deboned chest was significantly affected by diet $(\mathrm{P}=0.058)$ (Table 3 ). Chickens fed with the meat meal diet and the vegetable diet plus GAA showed the highest percentage weight. This result is interesting given the restrictions of some export markets on the use of animal meal in the diet of birds. There was no significant effect $(\mathrm{P}>0.05)$ on the weights of the chest and legs, with and without bone, or on the number and measurements of muscle fibers. 
Table 3. Muscle development (absolute and relative weights), number and diameter of pectoral muscle fibers $(\mu \mathrm{m})$, and muscle development (absolute and relative weights) of broiler legs at 7 days of age fed with diets including meat meal, GAA, or L-Arg.

\begin{tabular}{lcccccc}
\hline \multirow{2}{*}{ Variable } & $\begin{array}{c}\text { Vegetable } \\
\text { Diet }\end{array}$ & $\begin{array}{c}\text { Vegetable Diet } \\
\text { +FC }\end{array}$ & $\begin{array}{c}\text { Vegetable Diet }+ \\
\text { GAA }\end{array}$ & $\begin{array}{c}\text { Vegetable } \\
\text { Diet + L-Arg }\end{array}$ & CV, \% & P value \\
\cline { 2 - 7 } Breast with bone, g & 34.25 & 34.37 & 34.68 & 32.80 & 11.92 & 0.5169 \\
Breast with bone, \% & 15.60 & 15.85 & 16.29 & 15.36 & 7.79 & 0.1481 \\
Breast without bone, g & 25.53 & 26.35 & 26.77 & 25.53 & 15.52 & 0.5636 \\
Breast without bone, \% & $11.59^{\mathrm{b}}$ & $12.14^{\mathrm{a}}$ & $12.70^{\mathrm{a}}$ & $11.69^{\mathrm{b}}$ & 10.58 & 0.0585 \\
Muscular fiber, n/area & 116 & 117 & 115 & 112 & 16.68 & 0.9430 \\
Muscular fiber, diameter & 21.99 & 22.26 & 21.83 & 21.57 & 20.66 & 0.9854 \\
Legs with bone, g & 34.23 & 33.34 & 34.53 & 33.47 & 10.13 & 0.6748 \\
Legs with bone, \% & 15.59 & 15.40 & 15.79 & 15.57 & 4.22 & 0.3894 \\
Legs without bone, g & 26.45 & 25.61 & 26.62 & 25.59 & 12.73 & 0.6920 \\
Legs without bone, \% & $11.59^{\mathrm{b}}$ & $12.14^{\mathrm{a}}$ & $12.70^{\mathrm{a}}$ & $11.69^{\mathrm{b}}$ & 10.58 & 0.0585 \\
\hline
\end{tabular}

$\mathrm{CV}$ : coefficient of variation.

Hypertrophy of post-hatching muscle fibers occurs primarily in the longitudinal direction of the fiber, through an increase in the number of sarcomeres, and later, increases in diameter through the deposition of myofibrillar proteins. Thus, the contribution of fiber length at 7 days may have been greater than the diameter, since the sum of the two factors increased breast weight for the birds that consumed both the diet plus meat meal and the one with GAA, as observed in this study.

A similar result to that observed for the percentage weight of the deboned chest was recorded for the relative weight of the legs $(\mathrm{P}=0.0585)$ of broiler chickens (Table 3 ). Diets enriched with meat meal or GAA led to the highest percentage weights of boneless legs.
In this experiment, supplementation with GAA was more effective than with L-Arg at 7 days of age. Fernandes et al. (2009) observed significant improvements in the breast weight, breast fillet weight, and increase in muscle fiber diameter of broilers when they were fed diets supplemented with up to $300 \mathrm{mg} \mathrm{kg}^{-1} \mathrm{~L}$-Arg diet from 1 to 21 days of age, as compared to those fed on control diets.

There was no significant effect $(\mathrm{P}>0.05)$ of the diet on the serum biochemistry variables analyzed (Table 4). The biochemical composition of the blood accurately reflects the metabolic condition of animal tissues, enabling the evaluation of tissue damage, disorders of organ function, adaptation of the animal to nutritional and physiological challenges, and specific metabolic or nutritional imbalances (KANEKO et al., 1997). 
Table 4. Serum concentration of uric acid, creatine, glucose, lactate, and urea in broiler chickens at 42 days of age fed with diets including meat meal, GAA, or L-Arg.

\begin{tabular}{lcccccc}
\hline \multirow{2}{*}{ Diets } & $\begin{array}{c}\text { Vegetable } \\
\text { Diet }\end{array}$ & $\begin{array}{c}\text { Vegetable Diet } \\
+ \text { FC }\end{array}$ & $\begin{array}{c}\text { Vegetable Diet } \\
\text { + GAA }\end{array}$ & $\begin{array}{c}\text { Vegetable Diet } \\
\text { + L-Arg }\end{array}$ & CV, \% & P value \\
\cline { 2 - 7 } Uric acid, mg dL & 3.78 & 3.16 & 3.85 & 3.20 & 24.53 & 0.0980 \\
Creatine, $\mathrm{mg} \mathrm{dL}^{-1}$ & 0.19 & 0.24 & 0.25 & 0.26 & 53.05 & 0.4265 \\
Glucose, $\mathrm{mg} \mathrm{dL}^{-1}$ & 245.45 & 237.66 & 252.25 & 247.89 & 9.69 & 0.5296 \\
Lactate, $\mathrm{mg} \mathrm{dL}^{-1}$ & 5.13 & 5.31 & 5.30 & 5.66 & 58.74 & 0.9115 \\
Urea, $\mathrm{mg} \mathrm{dL}^{-1}$ & 3.94 & 4.63 & 4.23 & 4.68 & 27.28 & 0.4379 \\
\hline
\end{tabular}

$\mathrm{CV}$ : coefficient of variation.

The interpretation of the biochemical profile, applied to herds/lots or to individuals, is complex. The variability of responses presented by broiler chickens suggests that data of this nature should be observed in a greater number of birds per treatment, however, this becomes unviable in terms of cost and procedures.

Diet did not significantly affect carcass yield or commercial cuts (absolute and relative weights) $(\mathrm{P}>0.05)$ (Table 5). This result differs from the previous literature. Ringel et al. (2008) found a higher percentage of breast meat supplemented with GAA ( 0.6 to $\left.1.2 \mathrm{~g} \mathrm{~kg}^{-1}\right)$. The study developed by the EFSA Journal (2009), found that using GAA in doses of $800 \mathrm{mg} \mathrm{kg}^{-1}$ diet significantly increased breast weight and reduced abdominal fat. In addition, Michiels et al. (2012) found that dietary supplementation with GAA in a vegetable diet resulted in a higher percentage of breast meat when compared to non-supplemented birds and birds fed an animal diet. However, fat and leg weight did not differ significantly as a function of GAA supplementation.

Table 5. Absolute and relative values of carcass weight, commercial cuts, and abdominal fat of broiler chickens at 42 days of age fed with diets including meat meal, GAA, or L-Arg.

\begin{tabular}{lcccccc}
\hline \multirow{2}{*}{$\begin{array}{l}\text { Carcass } \\
\text { yield }\end{array}$} & \multirow{2}{*}{ Vegetable Diet } & $\begin{array}{c}\text { Vegetable Diet }+ \\
\text { FC }\end{array}$ & $\begin{array}{c}\text { Vegetable Diet }+ \\
\text { GAA }\end{array}$ & $\begin{array}{c}\text { Vegetable Diet } \\
\text { + L-Arg }\end{array}$ & CV, \% & P value \\
\cline { 2 - 7 } Carcass, g & 2375.82 & 2390.17 & 2472.00 & 2409.09 & 4.79 & 0.2206 \\
Carcass, \% & 76.11 & 75.93 & 76.76 & 75.93 & 2.68 & 0.9637 \\
Breast, g & 811.82 & 840.17 & 881.50 & 834.33 & 8.22 & 0.1213 \\
Breast, \% & 34.12 & 35.15 & 35.22 & 34.17 & 4.31 & 0.1532 \\
Legs, g & 660.64 & 646.67 & 685.00 & 671.50 & 5.42 & 0.0786 \\
Legs, \% & 27.83 & 27.05 & 27.73 & 27.57 & 5.11 & 0.5535 \\
Fillet, g & 271.09 & 282.33 & 294.83 & 273.50 & 10.50 & 0.2128 \\
Fillet, \% & 11.44 & 11.84 & 11.92 & 11.28 & 12.12 & 0.6339 \\
Sasami, g & 57.25 & 57.48 & 63.05 & 58.07 & 9.58 & 0.0536 \\
Sasami, \% & 2.42 & 2.40 & 2.55 & 2.38 & 9.54 & 0.3255 \\
Fat, g & 50.18 & 51.55 & 52.97 & 46.19 & 14.78 & 0.2091 \\
Fat, \% & 2.09 & 2.25 & 2.05 & 2.10 & 20.42 & 0.7190 \\
\hline
\end{tabular}

$\mathrm{CV}$ : coefficient of variation. 
Diet did not significantly affect $(\mathrm{P}>0.05)$ 6), color values ( $\mathrm{L}^{*}, \mathrm{a}^{*}$ and $\left.\mathrm{b}^{*}\right)$, or $\mathrm{pH}$ measured cooking, defrosting, and pressure loss results (Table before and after rigor mortis (Table 6).

Table 6. Losses because of cooking, freezing, and water holding capacity (WHC), values of luminosity (L*), red index $\left(\mathrm{a}^{*}\right)$, and yellow index ( $\left.\mathrm{b}^{*}\right)$ (expressed in the CIELAB color system), and $\mathrm{pH}$ of fillets of broiler chickens fed with diets including meat meal, GAA, or L-Arg.

\begin{tabular}{lcccccc}
\hline Quality variables & $\begin{array}{c}\text { Vegetable } \\
\text { Diet }\end{array}$ & $\begin{array}{c}\text { Vegetable Diet } \\
+ \text { FC }\end{array}$ & $\begin{array}{c}\text { Vegetable Diet } \\
+ \text { GAA }\end{array}$ & $\begin{array}{c}\text { Vegetable } \\
\text { Diet + L-Arg }\end{array}$ & CV, \% & P value \\
\cline { 2 - 7 } Cooking \% & 24.93 & 26.95 & 27.78 & 26.23 & 13.23 & 0.2525 \\
Freezing, \% & 3.98 & 4.71 & 5.28 & 4.75 & 56.82 & 0.3575 \\
WHC, \% & 10.75 & 10.47 & 10.81 & 11.17 & 19.02 & 0.8817 \\
L $^{*}$ & 50.74 & 51.47 & 52.99 & 53.77 & 58.76 & 0.9148 \\
$\mathrm{a}^{*}$ & 3.04 & 2.77 & 2.92 & 2.80 & 38.58 & 0.9299 \\
$\mathrm{~b}^{*}$ & 6.89 & 6.19 & 7.23 & 6.88 & 19.28 & 0.2757 \\
Initial pH & 6.42 & 6.37 & 6.36 & 6.46 & 2.55 & 0.4346 \\
Final pH & 5.58 & 5.40 & 5.45 & 5.56 & 4.03 & 0.1660 \\
\hline
\end{tabular}

CV: coefficient of variation.

Variations in the luminosity of raw breast meat may be associated with the amount of myoglobin, morphology, and $\mathrm{pH}$ of the muscle, since the rapid rate of postmortem glycolysis associated with high temperature causes denaturation of myoglobin, reflected in the lower color intensity (MENDES; KOMIYAMA, 2011). There was no difference in the $\mathrm{pH}$ values of the raw breast meat, so the luminosity of the fillets was not altered. In addition, Le-Bihan-Duval et al. (2001) assigned genetics with an important role in controlling the color of chicken breast meat and, therefore, diet may have a smaller impact on this characteristic.

Michiels et al. (2012) found slightly lower $\mathrm{pH}$ values for the GAA supplemented diets when compared to the non-supplemented vegetable diet and the animal protein diet. Nissen and Young (2006) found lower postmortem $\mathrm{pH}$ and lighter color in broiler chickens supplemented with CREA and glucose for 48 hours prior to slaughter. Stahl et al. (2003) found similar results when broilers were supplemented with CREA throughout the breeding period.
In studies on pigs, supplementation with CREA before slaughtering resulted in a slower decline in muscle $\mathrm{pH}$, positively related to water retention (BERG; ALLEE, 2001; JAMES et al., 2002; YOUNG et al., 2005).

Most research studies on CREA metabolism in muscle tissue were conducted with mammals, which makes it difficult to understand the mechanisms involved, since the amino acid metabolism in birds is different from that in mammals. Therefore, the effects of GAA on the meat characteristics of broilers should be studied and better understood. In this line of research, it is important to consider that dietary supplementation with GAA considerably increases the demand for methylation (MICHIELS et al., 2012), which may induce accumulation of homocysteine in the blood (SETOUE et al., 2008) or a deficiency of methionine, and even choline, folic acid, vitamin $\mathrm{B} 12$, or a combination of these factors, depending on the dietary availability of those nutrients in the diet. 


\section{Conclusion}

Including GAA or L-Arg in vegetable diets increased the live weight and percentage of muscle in the chest and legs of one-week-old broiler chickens. During the period from 1 to 42 days of age, the feed conversion was better in broilers fed with the vegetable diets plus meat meal.

The inclusion of GAA or L-Arg in vegetable diets did not influence the yield or quality of meat of broiler chickens at slaughter.

\section{References}

BAKER, D. H. Advances in protein-amino acid nutrition of poultry. Amino Acids, Berlin, v. 37, n. 1, p. 29-41, 2009.

BALL, R. O.; URSCHEL, K. L.; PENCHARZ, P. B. Nutritional consequences of interspecies differences in arginine and lysine metabolism. The Journal of Nutrition, Rockville, v. 137, n. 6, p. 1626-1641, 2007.

BERG, E. P.; ALlEE, G. L. Creatine monohydrate supplemented in swine finishing diets and fresh pork quality: I. A controlled laboratory experiment. Journal of Animal Science, Champaign, v. 79, n. 12, p. 3075-3080, 2001.

BLOCH, K.; SCHOENHEIMER, R. The biological precursors of creatine. The Journal of Biological Chemistry, Rockville, v. 138, n. 1, p. 167-194, 1941.

BRASIL. Ministério da Agricultura. Instrução Normativa $\mathrm{n}^{\mathrm{o}}$. 3, de 07 de janeiro de 2000. Regulamento técnico de métodos de insensibilização para o abate humanitário de animais de açougue. S.D.A./M.A.A. Diário Oficial [da] União, Brasília, 24 jan. 2000, Seção 1, p. 14-16.

BRYANT-ANGELONI, K. I. Dietary guanidinoacetic acid spares arginine and dietary l-homoserine spares threonine in the chick. 2010. Dissertação (Mestrado em Zootecnia) - Universidade de Illinois, UrbanaChampaign.

CHAMRUSPOLLERT, M.; PESTI, G. M.; BAKALLI, R. I. The influence of labile dietary methyl donors on the arginine requirement of young broiler chicks. Poultry Science, Champaign, v. 81, n. 8, p. 1142-1148, 2002.

DILGER, R. N.; BRYANT-ANGEONI, K.; PAYNE, R. L; LEMME, A.; PARSONS, C. M. Dietary guanidinoacetic acid is an efficacious replacement for arginine for young chicks. Poultry Science, Champaign, v. 92, n. 1, p. 171177, 2013.
DUBOWITZ, V. Muscle biopsy: a practical approach. $2^{\text {th }}$ ed. London: Bailliere Tindall, 1985. 720 p.

EDMONDS, M. S.; BAKER, D. H. Failure of excess dietary lysine to antagonise arginine in young pigs. Journal of Nutrition, Monticello, v. 117, n. 8, p. 13961401, 1987.

EFRON, D. T.; BARBUL, A. Arginine and immunonutrition: a reevaluation. Nutrition, Philadelphia, v. 16, n. 1, p. 73-74, 2000.

EUROPEAN FOOD SAFETY AUTHORITY - EFSA. Scientific opinion of the panel on additives and products or substances used in animal feed (FEEDAP) on a request from the European Commission on the safety and efficacy of CreAmino (guanidinoacetic acid) as feed additive for chickens for fattening. EFSA Journal, Parma, v. 7, n. 3., p. 1-30, 2009.

FERNANDES, J. I. M.; MURAKAMI, A. E.; MARTINS, E. N.; SAKAMOTO, M. I.; GARCIA, E. R. Effect of arginine on the development of the pectoralis muscle and the diameter and the protein: deoxyribonucleic acid rate of its skeletal myofibers in broilers. Poultry Science, Savoy, v. 88, n. 7, p. 1399-1406, 2009.

GREENHAFF, P. L. The nutritional biochemistry of creatine. The Journal of Nutritional Biochemistry, Rockville, v. 8, n. 11, p. 610-618, 1997.

HAMM, R. Biochemistry of meat hydration. Advances in Food Research, v. 10, p. 355-463, 1960.

JAMES, B. W.; GOODBAND, R. D.; UNRUH, J. A.; DRITZ, S. S. A review of creatine supplementation and its potential to improve pork quality. Journal of Applied Animal Research, Abingdon, v. 21, n. 1, p. 1-16, 2002.

KANEKO, J.; HARVEY, J.; BRUSS, M. Clinical biochemistry of domestic animals. $5^{\text {th }}$ ed. San Diego: Academic Press, 1997. 932 p.

KIDD, M. T.; KERR, B. J. L-Threonine for poultry: a review. Journal of Applied Poultry Research, Abingdon, v. 5, n. 4, p. 358-367, 1996.

LE-BIHAN-DUVAL, E.; BERRI, C.; BAEZA, E.; MILLET, C.; BEAUMONT, N. Estimation of the genetic parameters of meat characteristics and their genetic correlations with growth and body composition in an experimental broiler line. Poultry Science, Savoy, v. 80, n. 7, p. 839-843, 2001.

LÓPEZ, K. P.; SCHILLING, M. W.; CORZO, A. Broiler genetic strain and sex effects on meat characteristics, Poultry Science, Savoy, v. 90, n. 5, p. 1105-1111, 2011.

LOUIS, M.; POORTMANS, J. R.; FRACAUX, M.; BERRÉ, J.; BOISSEAU, N.; BRASSINE, E.; 
CUTHBERTSON, D. J. R.; SMITH, K.; BABRAJ, J. A.; WADDEL, T.; RENNIE, M. J. No effect of creatine supplementation on human myofibrillar and sarcoplasmic protein synthesis after resistance exercise. American Journal of Physiology - Endocrinology Metabolism, London, v. 285, n. 5, p. 1089-1894, 2003.

MAPES, J. P.; KREBS, H. A. Rate-limiting factors in urate synthesis and gluconeogenesis in avian liver. Biochemical Journal, Essex, v. 172, n. 2, p. 193-203, 1978.

MENDES, A. A.; KOMIYAMA, C. M. Estratégias de manejo de frangos de corte visando qualidade de carcaça e carne. Revista Brasileira de Zootecnia, Viçosa, MG, v. 40, p. 352-357, 2011. Suplemento Especial.

MICHIELS, J.; MAERTENS, L.; BUYSE, J.; LEMME, A.; RADEMACHER, M.; DIERICK, N. A. de SMETH, S. Supplementation of guanidinoacetic acid to broiler diets: effects on performance, carcass characteristics, meat quality, and energy metabolism. Poultry Science, Savoy, v. 91, n. 2, p. 402-412, 2012.

MOUSAVI, S. N.; AFSAR, A.; LOTFOLLAHIAN, H. Effects of guanidinoacetic acid supplementation to broiler diets with varying energy contents. Journal of Applied Poultry Research, Athens, v. 22, n. 1, p. 47-54, 2013.

NISSEN, P. M.; YOUNG, J. F. Creatine monohydrate and glucose supplementation to slow and fast growing chickens changes the postmortem $\mathrm{pH}$ in Pectoralis major. Poultry Science, Savoy, v. 85, n. 6, p. 1038-1044, 2006.

RINGEL, J.; LEMME, A.; ARAUJO, L. F. The effect of supplemental guanidine acetic acid in Brazilian type broiler diets at summer conditions. Poultry Science, Savoy, v. 87, n. 154, 2008. Supplement 1.

SAVAGE, J. E.; O'DELL, B. L. Arginine requirement of the chick and the arginine-sparing value of related compounds. The Journal of Nutrition, Rockville, v. 70, n. 2, p. 129-134, 1960.

SETOUE, M.; OHUCHI, S.; MORITA, T.; SUGIYAMA, $\mathrm{K}$. Hyperhomocysteinemia induced by guanidinoacetic acid is effectively suppressed by choline and betaine in rats. Bioscience, Biotechnology, and Biochemistry, Tokyo, v. 72, n. 7, p. 1696-1703, 2008.
SMITH, M. O. Parts yeld of broilers reared under cycling high temperatures. Poultry Science, Savoy, v. 72, n. 6, p. 1146-1150, 1993.

STAHL, C. A.; GREENWOOD, M. W.; BERG, E. P. Growth parameters and carcass quality of broilers fed a corn-soybean diet supplemented with creatine monohydrate. International Journal of Poultry Science, Faisalabad, v. 2, n. 6, p. 404-408, 2003.

STATISTICAL ANALYSIS SYSTEM INSTITUTE SAS Institute. User's guide. Cary: SAS Institute, 2002. $525 \mathrm{p}$.

VOLEK, J. S.; RATAMESS, N. A.; RUBIN, M. R.; GÓMEZ, A. L.; FERNCH, D. N.; MCGUIGAN, M. M.; SCHEETT, T. P.; SHARMAN, M. J.; HÄKKINEN, K.; KRAEMER, W. J. The effects of creatine supplementation on muscular performance and body composition responses to short-term resistance training overreaching. Euroupean Journal of Applied Physiology, Cham, v. 91, n. 5, p. 628-637, 2004.

VOLEK, M.H.;BRANCH, J.D. Creatine supplementation and exercise performance: an update. The Journal of the American College of Nutrition, Clearwater, v. 17, n. 3, p. 216-234, 1998.

WALKER, J. B. Metabolic control of creatine biosynthesis. I. Effect of dietary creatine. Journal of Biological Chemistry, Rockville, v. 235, p. 2357-2361, 1960.

WILHELM, A. E.; MAGANHINI, M. B.; BLAZQUEZ, F. J. H.; IDA, E. I.; SHIMOKOMAKI, M. Protease activity and the ultrastructure of broiler chicken PSE (Pale, soft, exsudative) meat. Food Chemistry, Hamburg, v. 119, n. 3, p. 1201-2004, 2010.

WIETLAKE, A. W.; HOGAN, A. G.; O’DELL, B. L.; KEMPSTER, H. L. Amino acid deficiencies of casein as a source of protein for the chick. The Journal of Nutrition, Rockville, v. 52, n. 2, p. 311-323, 1954.

YOUNG, J. F.; BERTRAM, H. C.; ROSENVOLD, K.; LINDAHL, G.; OKSBJERG, N. Dietary creatine monohydrate affects quality attributes of Duroc but not Landrace pork. Meat Science, Amsterdan, v. 70, n. 4, p. 717-725, 2005. 